\title{
The Norwegian nutrition campaign: setting goals and assessing results
}

\author{
By C. R. Blythe, Collingwood House, Pound Corner, Barcombe, Lewes, East
} Sussex BN8 ${ }_{5} T L$

Surprisingly, in view of Norway's radical and innovative nutrition and food policy (Royal Norwegian Ministry of Agriculture, 1975-76), there is little systematic teaching of nutrition in Norwegian schools, at any level. This lack is partly compensated by a programme of public nutrition education sponsored by government and voluntary agencies and disseminated through the mass media and grass-roots organizations. Behind the national campaign described here, there is a committed, well-organized nutrition 'establishment' and a government which is persuaded that a dietary shift would benefit health, the economy and Norway's food security. A brief account of the health background and a mention of the risk-factor intervention programmes will serve to put the main preoccupations behind the Norwegian national nutrition policy into context.

Coronary heart disease (CHD) and cancer are responsible for about $70 \%$ of deaths in Norway; CHD is also the largest cause of premature death in men over the age of $4 \circ$ years. Risk factors which in adults are indicative of CHD have also been detected in schoolchildren (Tell, 1983). The sharp rise in CHD deaths in the I 950 s and r960s prompted several epidemiological studies (fifteen to date) which, in recent years, have been combined with screening and intervention programmes (Bjartveit et al. 1979). Despite reservations from sections of the Norwegian medical profession about the validity of and ethical justification for intervention (see Bjartveit et al. 1979), the success of the intervention studies has served to establish clearly in the public and political minds that the incidence of CHD can be reduced by altering diets or cutting down on smoking, or both. This evidence of effectiveness has provided the nutrition lobby with a strong lever in negotiating government support for the sort of campaign which took place in 1982 .

The Nutrition Campaign was launched in February 1982 with a press conference, television and radio items and a series of articles in the national press; campaign posters were displayed in streets and on public transport. Fact sheets, school books, wall charts and even games were produced but the campaign was largely centred around the widely-advertised book Everyday Food (National Nutrition Council, $1982 a$ ).

A noticeable characteristic of the campaign was lightness of touch. Dietary goals were presented as (or translated into) a series of small, easily-achievable changes in the daily meal routine. Prohibitions were avoided, there being an implicit recognition that if you allow people to 'sin' now and then, they may find it easier to behave the rest of the time! A major theme of the campaign was that, if you eat sensibly during the week, you can safely eat more or less what you like at the weekends. Educational material for young children developed this idea of 'everyday 
food' and food to enjoy at weekends in a graded series of books entitled Best Friends and Saturday Friends.

Given the preoccupation with heart disease and cancer, it is to be expected that the campaign should have concentrated on the need to eat less fat and more fibre. Among simple ideas for reducing fat intake were: mix skimmed and whole milk half and half, spread margarine or butter on the 'wrong' side of your crispbread (the side without the 'holes') and use some of the new low-fat varieties of traditional soured dairy products on fish and salad, instead of oil-rich mayonnaise. People were encouraged to think about how much margarine or butter they spread on bread. Taking six slices of bread daily as an average, it was claimed that spreading butter thinly (say $3 \mathrm{~g} / \mathrm{slice}$ ) could use up to $13 \mathrm{~kg}$ less/person per year than if it were spread on thickly (say $9 \mathrm{~g} /$ slice).

There was a strong emphasis on involving people at local levels. Workers' organizations, works canteens, institutional caterers, women's organizations, libraries and even small local food shops were canvassed and persuaded to make their own contribution to the campaign, by holding discussion groups, re-thinking the canteen menu, stocking and advertising a wider range of fresh and whole foods, putting up poster displays or simply putting a pile of brochures on the counter. The bakers' organization enthusiastically funded a campaign within a campaign to increase sales of brown bread, with some success.

Evaluating the campaign really boils down to getting the answers to three simple questions: How many people knew of the campaign? Did those it reached understand what was being put across? What changes in eating habits resulted, if any? Primary evaluation was conducted by the Division of Social Information of the Norwegian School of Management (Thjømøe, 1983). A sample of 1219 people were interviewed before, during and after the campaign and their changing attitudes and knowledge recorded. At the time of writing, published results cover only the first 6 months of 1982 ; these broadly indicate that by June, $10 \%$ more people were persuaded that eating less fat and more fibre would be good for them than thought so in February. The organizers believe that $72 \%$ of the population got to know of the campaign, with women much better informed than men (National Nutrition Council, $1982 b$ ). The campaign recipe and information book Everyday Food (National Nutrition Council, 1982a) sold around 100000 copies and, while that figure represents only approximately $2.5 \%$ of the population, it was nonetheless a remarkable achievement in the recessionary context of book sales generally. Of the sample mentioned earlier $43 \%$ had heard of Everyday Food and $13.4 \%$ claimed to have read or at least glanced through the book.

Circumstances which could not have been anticipated when the campaign was planned have conspired to make it difficult to assess any impact the campaign may have had on eating habits, at least during 1982 . For pressing economic reasons consumer subsidies on meat and flour were reduced early in 1982 . In the case of flour, foreknowledge of the price rises caused some stockpiling, after which sales fell bèlow I98I levels. Another possibly complicating factor is that the 1982 summer was abnormally hot in Norway and this may have further depressed 
summer bread consumption and, hence, that of margarine and butter. Encouragingly, although total flour sales (including rye, barley and oats) fell during 1982, whole-wheat flour improved its position relative to white flour by $2.8 \%$ (A. Løchen, National Nutrition Council, personal communication).

As to the teaching of nutrition in schools, nutrition studies are offered as a I-year optional extra to the teacher-training course but uptake has been poor. Courses have been criticized as being too academic for elementary-grade teachers to be able to use them. As one (necessarily anonymous) commentator said: ' $\ldots$. it's of no importance to children to know about carboxyl groups, they need to know which foods provide calcium for growing bones.' It is also the view of some that, until recently, a lack of attractive, suitably-pitched material was chiefly responsible for nutrition receiving so little attention in schools (E. Ziglio, Department of Social Administration, University of Edinburgh, personal communication). The 1982 campaign organizers set out to remedy the lack of suitable school material and considerable thought was given to developing a sequence of publications which could take students through from primary to final grades. Norwegian teachers have considerable autonomy and, within accepted limits, may teach what they like, when they like. To persuade more teachers to include nutrition in the curriculum, staff from the National Association for Diet and Health go into schools to give specimen lessons and run short courses for teachers. As an added incentive, much of the campaign material is available free to schools.

\section{REFERENCES}

Bjartveit, K., Foss, O. P. Gjervig, T. \& Lund-Larsen, P. G. (1979). The Cardiovascular Disease Study in Norwegian Counties; Background and Organisation. Oslo: National Mass Radiography Service.

National Nutrition Council (1982a). Everyday Food appears in Norwegian as Hver Dags Mat. Oslo: Statens Informasjonstjeneste, NKS-Forlaget.

National Nutrition Council $(1982 b)$. Inter-sectorial action for nutrition and health: Norwegian policy. Paper presented at Workshop for Inter-sectorial Action for Nutrition and Health, Trevandrum, Kerala, India, 22-26 November 1982. Oslo: National Nutrition Council.

Royal Norwegian Ministry of Agriculture (1975-76). Report to the Storting no. 32, Norzvegian Nutrition and Food Supply Policy. Oslo: Royal Norwegian Ministry of Agriculture. (In English).

Tell, G. S. ( $\left(9^{8} 83\right)$. The current health status of Norwegian youth. Paper presented at WHO Workshop on Health Promotion and Youth, Heidelberg. Oslo: Institute of Preventive Medicine.

Thjømøe; H. M. (1983). Samfunnsinformasjon: Problemer og Muligheter belyst ved en evaluering $a v$ Ernaeringskampanjen 1982. Forskningsrapport January 1983. Bekkestua: Bedriftsøkonomisk Institutt. 